期 (CNSDC) からIV期 (肝硬変) に分けられ ている．本症は自己免疫性疾患とりわけシェー グレン症候群との合竍率が高い。治療には I 期, II期ないしIII期の症例にはUDCA療法が第一選 択であり，現在は $90 \%$ 以上の症例に行われてい る. UDCA抵抗例にはコルヒチンやメソトレキ セートの投与も試みられている。一方，免疫抑 制剤の長期使用は副作用の面から問題がある. 描痒にコレスチラミン，骨粗䉘症に活性ビタミ ン $\mathrm{D}_{3}$ の投与が行われるが，最近は高胆道系酵素 血症に対しべザフィブレイト投与の報告があ る。食道静脈瘤には硬化療法や結禁療法に上る コントロールが必要である。死因の主なものは
肝不全と食道静脈瘤破裂である.UDCAの有効 性については組織像の改善は期待出来ないとす る意見がある一方, 本邦では1990年以降に登録 された症例の生存率はそれ以前の症例に比し, 有意に改善されており，特に組織学的進展度の 低い発黄例で著しいところからUDCA療法が予 後に好影響を与えていると推定されている。し かし血中ビリルビン $8 \mathrm{mg} / \mathrm{dl}$ 以上のIV期症例は その改善が見られず, 肝移植を検討すべきであ る、また, 従来PBCには肝細胞癌の発生は稀と 考えられていたが，3.8\%の合併が報告されて おり注意を必要とする。

\title{
3. 真菌感染症
}

\section{長崎大学第二内科 河野 茂}

深在真菌感染症はヒト細胞と同様の真核生物 である真菌を原因微生物とする感染症である。 深在性真菌感染症の多くは免疫不全患者の日和 見感染症として発症するため，ひとたび診断お よび治療が遅れれば, 患者の予後に大きく影響 する。

真菌症の発症には，原因真菌の病原性ととも に生体の好中球やリンパ球, 単球を中心とした さまざまな生体防御機構がその発症に関係して いる。

真菌の培盖や病理診断は困難なことが多く, 真菌の細胞成分を抗原とする血清診断やPCR法
を用いた遺伝子診断が行われている。しかし， これら診断法も感度や特異性に解決すべき問題 が残されている. 抗真菌薬はこの10数年間に抗 真菌活性および安全性に優れた薬剤が開発され ている、しかし，いまだ抗真菌薬が無効な真菌 症や耐性菌の出現など多くの問題が解決されて いない.

最近のトピックスとして，クリプトコックス など病原真菌の全ゲノム解析が進行中である. 近い将来，これを応用した真菌の病原性や新規 薬剤開発への応用などの研究成果が期待されて いる.

\section{4. 心疾患の救命救急：院外での処置が生死を分ける}

\section{岩手医科大学第二内科 平盛勝彦}

循環器疾患は日本人の死因の第一であり,そ の死亡の大多数は急死である。また，急死に至
る疾患の第一が循環器疾患であり，そのうち最 も多いのが心筋梗塞症である.さらに的確迅速 
な処置によって多数を救命できるのも心疾患に 特徵的である。

心疾患死の大部分は院外で発生する。搬送さ れてくる患者さんを病院で待っているのでは多 くを救えない.「院外での救命救急システム」が 必須であり，これとの連動を欠いた救急診療の 効用はごく小さい.このシステムが整えば，救 命されて社会復帰できる症例は現況の10倍を越 える．死が心疾患ほど急ではない急患をもよく 救えるようになる．現況の医学と医療のあり方 のフォーカスを院外へ定め直すべきである.

院外での心停止例救命救急の第一は救急隊人 の出動要請，第二が倒れた人の傍らにいる人に よる心肺蘇生法, 第三が救急隊による救命処置, 第四が救急病院での治療である．この全てがき ちんと行われ，遅れなく慗がれば30\%ほどの例 が救命されて社会復帰できる。 そのような救命
救急システムを営んでいるところが欧米各地に ある．日本での救命率は平均して $3 \%$ ほどであ る. 欧米では, 心疾患専門医とその学会が先導 し，地域の各組織とともに救急システム作りを 進めている，日本には，それがない。専門医と その学会のあり方が正され，医療に携わるるも の全てがこれに与する賑わいがほしい.また， その出来のいかんは, この国が, 命と健康をど れほどに大切なものとするかに従うものである. 上記について概説するとともに，岩手県心肺 蘇生法普及県民運動などの各地での取り組み， 地域のCCUネットワーク, 日本心肺蘇生法協 議会, 救急救命士, 日本の救急医療制度, 市民 が行う電気的除細動を含む欧米の救急システム などの現況を紹介する，その上で，いま，医療 従事者に，また国と社会に望みたい行いについ て思うところを述べたい。

\section{5. 老人性肺炎診療の新戦略}

東北大学老年科 佐々木英忠

老人性肺炎は日本人の第 3 位の死亡率，男女 共で 4 位と重要な疾患である. 肺炎発症後抗生 物質で治療してもすぐ再発を扢こし，予防が求 められている。老人性肺炎は大脳基底核の脳血 管障害で発生するが，大脳基底核で作られる ドーパミンの減少のため, 嚥下反射と咳反射が 低下して不顕性誤嚥をおこすことによって生じ
る、ACE阻害剂（イミダプリル）はサプス夕 ンス $\mathrm{P}$ 上昇させ，曣下反射を改善し， 2 年間 の投与によって肺炎発症を $1 / 3$ に隇少させた。 又,ドーパミン合成を促進するアマンタジン (100mg) を 3 年間投与し，肺炎発症を $1 / 5$ に 減少させた.

\section{6. $\operatorname{IgA}$ 腎症の臨床}

\section{新潟大学第二内科 下条文武}

IgA腎症は，日本人に最も多く見られる原発 性糸球体腎炎であり，血尿とさまざまな程度の 蛋白尿がみられる.臨床像は多彩であり, 約 $1 / 3$
は慢性の経過で腎機能が低下し，末期腎不全に いたる. 教室の468例の検討では, Kaplan-Meier 法による累積腎死率は, 腎生検から10年で19\%， 